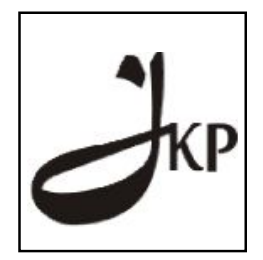

Jurnal Konseling dan Pendidikan

ISSN Cetak: 2337-6740 - ISSN Online: 2337-6880

http://jurnal.konselingindonesia.com

Volume 3 Nomor 1, February 2015, HIm 1-6

Info Artikel:

Diterima 02/02/2015

Direvisi 18/02/2015

Dipublikasikan 28/02/2015

\title{
Pengembangan Karakter Jujur Melalui Pembiasaan
}

Juliana Batubara

IAIN Imam Bonjol, Padang

\begin{abstract}
Honesty is a the important character in the student. The creation of this character takes quite a long time and cannot be conducted in an instant. Honest character can be developed using the behavioristik theory by conditioning with stimulus-response technique-reinforcement. The role of teacher, counselors, other school personnel, parents and the community are very important in the development of the student's characters through conditioning.
\end{abstract}

Keyword: Honesty_character, conditioning

Copyright ( 2015 IICE - Multikarya Kons (Padang - Indonesia) dan IKI - Ikatan Konselor Indonesia - All Rights Reserved

Indonesian Institute for Counseling and Education (IICE) Multikarya Kons

\section{PENDAHULUAN}

Pendidikan bagi kehidupan manusia merupakan kebutuhan primer yang harus dipenuhi sepanjang hayat. Tanpa pendidikan sama sekali mustahil suatu kelompok manusia dapat hidup berkembang dengan cita-cita untuk maju, sejahtera, dan bahagia menurut konsep pandangan hidupnya. Hal ini sejalan dengan fungsi dan tujuan pendidikan nasional, sebagaimana tercantum dalam Undang-undang RI No. 20 Tahun 2003 tentang Sistem Pendidikan Nasional Pasal 1 butir 1, yang berbunyi

Pendidikan merupakan usaha sadar dan terencana untuk mewujudkan suasana belajar dan proses pembelajaran agar peserta didik secara aktif mengembangkan potensi dirinya untuk memiliki kekuatan spiritual keagamaan, pengendalian diri, kepribadian, kecerdasan, akhlak mulia, serta keterampilan yang diperlukan dirinya, masyarakat, bangsa dan negara.

Dalam pengertian sederhana makna pendidikan adalah usaha sadar manusia untuk menumbuhkembangkan potensi-potensi pembawaan baik jasmani maupun rohani sesuai dengan nilai-nilai yang ada di dalam masyarakat dan agama. Adapun tujuan pendidikan nasional yang tecantum dalam Undang-undang RI No. 20 Tahun 2003 tentang Sistem Pendidikan Nasional adalah

Berkembangnya potensi peserta didik agar menjadi manusia yang beriman dan bertaqwa terhadap Tuhan Yang Maha Esa, berakhlak mulia, sehat, berilmu, cakap, kreatif, mandiri dan menjadi warga negara yang demokratis serta bertanggung jawab.

Tujuan pendidikan yang sangat mulia itu belum sepenuhnya tercapai, walaupun tidak sepenuhnya dikatakan gagal. Berdasarkan realita ujian akhir nasional, salah satu agenda besar dalam pendidikan di Indonesia yang akan menentukan "nasib" peserta didik apakah lulus atau tidak dari satu jenjang pendidikan. Ujian nasional (UN) menjadi momok yang masih menakutkan, karena hasil ini masih memiliki peran besar dalam menentukan lulus tidaknya peserta didik. Salah satu kejadian yang sering terjadi dalam pelaksanaan UN adalah ketidak jujuran peserta didik dalam mengerjakan. Mereka mengerjakan soal dengan menyontek dari teman lain, atau dari catatan yang dibuat sebelumnya. Selain itu di beberapa sekolah ada juga guru yang mendukung tindakan peserta didik tersebut untuk tidak jujur dalam UN. Karena mereka tidak mau ambil resiko, yang mereka inginkan adalah peserta didik yang diajar bisa 100\% lulus menempuh UN, sehingga citra sekolah di mata umum tetap baik.

Inilah kondisi yang terjadi setiap tahun dalam dunia pendidikan. Kondisi ini berbanding lurus dengan kenyataan mengenai kebobrokan pemerintah sekarang. Penyelenggaraan pendidikan menjadikan peserta didik 
berbuat curang dan tidak jujur bahkan sampai kepemerintah yang selalu melakukan praktik KKN dalam berbagai macam aspek.

Fenomena ini terjadi karena pudarnya nilai-nilai karakter pada bangsa yang menjadi cerminan dalam kehidupan. Karakter merupakan nilai-nilai perilaku manusia yang berhubungan dengan Tuhan Yang Maha Esa, diri sendiri, sesama manusia, sikap, perasaan, perkataan dan perbuatan berdasarkan norma-norma agama, hukum, tata krama, budaya dan adat istiadat. Memudarnya nilai-nilai karakter bangsa tidak hanya pada pelajar, tapi juga di masyarakat dan di lingkungan kerja.

Berdasarkan fenomena di atas pendidikan memiliki peran penting dan sentral dalam pengembangan potensi manusia, termasuk potensi mental. Melalui pendidikan diharapkan terjadi transformasi yang dapat menumbuhkembangkan karakter yang positif, serta mengubah watak dari yang tidak baik menjadi baik (Kemendiknas, 2010). Dalam berbagai aturan, panduan, pedoman resmi yang dikeluarkan pemerintah ditegaskan bahwa pendidikan karakter bukan merupakan mata pelajaran atau sebagai pokok bahasan melainkan terintegrasi kedalam mata pelajaran, muatan lokal, pengembangan diri melalui proses pembelajaran dan budaya satuan pendidikan (Direktorat Ketenagaan Ditjen Dikti Kemdiknas, 2010; Kementerian Pendidikan Nasional, Badan Penelitian dan Pengembangan Pusat Kurikulum, 2010a, 2010b; Kementerian Pendidikan Nasional Badan Penelitian dan Pengembangan Pusat Kurikulum dan Perbukuan, 2011a, 2011b). Untuk mewujudkan pendidikan karakter ini dibutuhkan peran guru, guru BK atau konselor, personil sekolah lainnya serta orangtua dan masyarakat.

\section{KARAKTER JUJUR DAN STRATEGI PENGEMBANGANNYA}

Pendidikan karakter mempunyai makna lebih tinggi daripada pendidikan moral, karena bukan sekedar mengajarkan mana yang benar dan mana yang salah. Lebih dari itu pendidikan karakter menanamkan habit tentang mana yang baik dan buruk, mampu merasakan nilai yang baik dan bisa melakukannya. Jadi pendidikan karakter erat kaitannya dengan habit yang terus menerus dilakukan.

Pengertian Karakter Jujur

Istilah karakter cenderung dihubungkan dengan istilah-istilah lain yang berkonotasi positif sebagaimana yang dijelaskan dalam Kerangka Acuan Pendidikan Karakter Tahun 2010 oleh Direktorat Ketenagaan Ditjen Dikti Kemdiknas, 2010 (dalam Daharnis, 2013:3) bahwa:

Istilah karakter dihubungkan dan dipertukarkan dengan istilah etika, akhlak, dan atau nilai yang berkaitan dengan kekuatan moral, berkonotasi positif bukan netral. Dengan demikian karakter adalah nilai-nilai yang unik-baik yang terpatri dalam diri dan terejawantahkan dalam perilaku. Karakter secara koheren memancar dari hasil olah pikir, olah hati, olah rasa dan karsa, serta olahraga seseorang atau sekelompok orang.

Menurut Kamus Besar Bahasa Indonesia (1995:445), karakter memiliki arti sifat-sifat kejiwaan, akhlak atau budi pekerti yang membedakan seseorang dari yang lain. Menurut Prayitno (2011:15) karakter adalah sifat pribadi yang relatif stabil pada diri individu yang menjadi landasan bagi penampilan perilaku dalam standar nilai dan norma yang tinggi. Adapun yang dimaksud dengan sifat pribadi yang relatif stabil adalah ciri yang ada di dalam pribadi seseorang yang terwujud dalam tingkah laku yang apabila telah terbentuk akan tidak mudah diubah. Hal ini dapat terbentuk karena adanya landasan yang kuat pengaruhnya berkaitan dengan agama, ilmu, hukum, adat dan kebiasaan yang tercermin dalam kehidupan sehari-hari.

Menurut Daniel Goleman (2011:79), pendidikan karakter merupakan pendidikan nilai, yang mencakup sembilan nilai dasar yang terkait, yaitu "responsibility (tanggung jawab), respect (rasa hormat), fairnes (keadilan), Courage (keberanian), honesty (kejujuran), citizenship (rasa kebangsaan), self-discipline (disiplin diri), caring (peduli), dan perseverance (ketekunan)".

Salah satu nilai karakter yang sangat penting dalam kehidupan adalah kejujuran. Kejujuran merupakan tingkah laku yang dimiliki oleh seorang individu dalam mengakui, berkata atau memberikan suatu informasi yang sesuai dengan kenyataan dan kebenaran. Individu terkadang melupakan nilai dari kejujuran itu sendiri. Kejujuran merupakan pangkal keimanan seseorang dalam menata hidupnya.

Menurut Albert Hendra Wijaya (dalam Emosda, 2013) bahwa jujur jika diartikan secara baku adalah mengakui, berkata atau memberikan suatu informasi yang sesuai dengan kenyataan dan kebenaran. Dalam Kamus Besar Bahasa Indonesia (1995:440) kata jujur berarti: tidak bohong, lurus hati, dapat dipercaya kata-katanya, tidak khianat. Jika seseorang berkata tidak sesuai dengan kebenaran dan kenyataan atau tidak mengakui suatu hal sesuai 
dengan apa adanya, maka orang tersebut dapat dianggap atau dinilai tidak jujur, menipu, mungkir, berbohong, munafik dan sebagainya.

Hal ini sesuai dengan ayat $\mathrm{Al}$ Qur'an dalam surat 5 ayat 8 berkaitan dengan pengertian jujur, yang artinya:

Hai orang-orang yang beriman, jadilah kamu sebagai penegak keadilan karena Allah

(menjadi saksi dengan adil). Dan janganlah sekali-kali kebencianmu terhadap suatu kaum,

mendorong kamu untuk berlaku tidak adil. Berlaku adillah, karena adil itu lebih dekat

kepada taqwa, Dan bertaqwalah kepada Allah, sesungguhnya Allah Maha mengetahui apa

yang kamu kerjakan.(QS:5:8)

Berdasarkan definisi di atas dapat disimpukan bahwa kejujuran akan tercermin dalam prilaku berbicara sesuai dengan kenyataan, berbuat sesuai bukti dan kebenaran. Dengan demikian kejujuran merupakan salah satu unsur kekuatan spiritual, akhlak mulia, serta kepribadian.

Tingkatan Jujur

Kejujuran sebagian dari karakter. Secara umum karakter dapat dipandang sebagai watak yang dimiliki oleh seorang individu yang bersifat khas atau istimewa yang berupa tingkah laku atau sikap. Banyak hal yang dapat mempengaruhi terbentuknya karakter baik yakni dari dalam diri individu maupun dari luar individu.

Ciri-ciri orang yang memiliki kejujuran yaitu tidak berbohong, tidak mengingkar janji, tidak menipu, serta mengakui kesalahan merupakan dasar pegangan dalam berbuat jujur. Kejujuran dapat praktikkan dalam kehidupan sehari-hari, baik lingkungan pribadi sendiri, lingkungan keluarga maupun lingkungan sosial. Interaksi sangat menentukkan timbulnya suatu kejujuran atau kebohongan dari seorang individu

Menurut Sa'id Hawwa (2007:346) tingkatan jujur ada lima, yaitu:

a. Jujur dalam perkataan. Kejujuran dalam perkataan dapat diketahui ketika seseorang memberikan suatu berita.

b. Jujur dalam niat. Hal ini berkaitan dengan keikhlasan. Kejujuran dalam niat dapat diketahui ketika sesorang melakukan sesuatu karena keikhlasan, tanpa meminta imbalan.

c. Jujur dalam memenuhi keinginan. Bagi seseorang mudah mengungkapkan keinginannya, akan tetapi untuk merealisasikannya cukup berat. Dalam hal ini diperlukan kejujuran pada diri idividu untuk merealisasikannya.

d. Jujur dalam perbuatan. Hal ini menunjukkan kesungguh-sungguhan seseorang dalam mengerjakan sesuatu sesuai dengan apa yang ada di dalam hatinya.

e. Jujur dalam beragama. Hal inilah yang merupakan kejujuran yang paling tinggi dan mulia.

Uraian di atas senada dengan pendapat Irwan Rinaldi (2014) yang mengatakan bahwa tingkat kejujuran terdiri dari lima yaitu: jujur dalam berbicara, jujur dalam niat, jujur dalam merealisasikan, jujur dalam bertindak dan jujur dalam beragama. Sikap jujur harus dimiliki oleh seseorang sejak dini. Kejujuran dapat dibentuk melalui pendidikan. Jika kejujuran sudah diterapkan sejak dini, maka karakter yang baik dapat dibentuk. Menurut Prayitno dan Afriva Khaidir (2011), dan Tim Penyusun P3N-KC (2011) nilai karakter cerdas jujur adalah sebagai berikut.

1) Berkata apa adanya

2) Berbuat atas dasar kebenaran

3) Membela kebenaran

4) Bertanggung jawab

5) Memenuhi kewajiban dan menerima hak

6) Lapang dada

7) Memegang janji

Untuk mencapai tingkat kejujuran itu, sekolah yang merupakan salah satu lingkungan pendidikan memiliki peran penting setelah keluarga. Hal ini dapat diwujudkan dengan teknik pembelajaran pembiasaan. Oleh karena itu prinsip yang harus dipegang dalam pendidikan adalah kejujuran yang menjadi nilai terbaik dan harus dimiliki siapapun. Inilah ranah pendidikan yang mestinya diterapkan. Pendidikan menjunjung tinggi nilai-nilai kejujuran. Pendidikan tidak berorientasi pada kondisi peserta didik yang harus lulus ujian, meski dengan cara-cara yang tidak benar. Pendidikan yang tidak memandang segalanya dari nilai rapor, hasil semesteran belaka atau IPK, melaiankan pendidikan yang mampu untuk membentuk karakter pada diri peserta didik.

Strategi Mengembangkan Karakter Jujur Peserta Didik

Sistem pendidikan yang baik adalah sistem pendidikan yang mampu menghasilkan manusia yang terdidik secara keilmuan, serta mengerti baik dan buruk terhadap sesuatu hal. Sehingga ilmu yang diperoleh tidak akan 
disalahgunakan untuk berbuat kejahatan, karena sudah tertanam karakter yang baik dalam jiwa setiap siswa. Untuk mewujudkan ini ada empat hal penting yang perlu diperhatikan oleh guru, termasuk guru bimbingan dan konseling atau konselor dalam menanamkan nilai-nilai kejujuran pada anak didik, yaitu:

a) Isi materi yang diajarkan kepada anak didik hendaknya dikaitkan dengan kenyataan dan praktek yang ada di lingkungan luar.

b) Adanya kondisi lingkungan yang jujur, mulai dari keluarga, sekolah, teman sebaya. Kurikulum dan isi pengajaran secanggih apapun akan kurang berdaya guna apabila kondisi tersebut tidak biasa diciptakan. Sangat ironis bila pendidik memberikan teladan ketidakjujuran dalam pelaksanaan tugasnya.

c) Pengenalan diri, tugas, fungsi dan peran serta kemampuan bertindak sesuai dengan aturan sangat perlu dalam menumbuhkembangkan karakter jujur.

d) Pentingnya pembentukan kemauan dan kehendak yang kuat dalam proses pendidikan untuk membiasakan peserta didik dengan soft skill yang diperlukan dalam kehidupan.

Menurut Alfauruzy (2012) ada beberapa program pendidikan yang dapat membantu sekolah dalam mengembangkan kejujuran peserta didik, diantaranya:

a) Kantin kejujuran. Program ini akan melatih peserta didik ketika dia membeli makanan tanpa ada penjaganya, apakah akan tetap membayar dengan utuh, atau dikurangi, sehingga peserta didik terbiasa berbuat jujur.

b) Setiap ujian dilakukan, soal yang diberikan oleh seorang guru lebih baik sedikit tetapi setiap peserta didik berbeda. Hal ini akan menghindari perbuatan curang yang sering terjadi.

c) Menyeimbangkan aspek hukuman dan penghargaan. Menghargai seseorang karena karyanya dianggap bagus oleh orang lain merupakan kebahagiaan yang sangat berharga. Apalagi ini terjadi pada peserta didik yang diberi penghargaan atau sekedar ucapan selamat oleh gurunya atas prestasi yang diraihnya.

d) Proses penilaian bukan hanya dari hasil ujian saja, tetapi juga bagaimana cara mendapatkan jawaban soal itu. Dengan memperhatikan proses belajar siswa, maka sebenarnya peserta didik telah dididik bagaimana cara mengerjakan sesuatu dengan cara yang benar.

e) Evaluasi hasil dari proses belajar. Hal ini menjadi wajib dalam pendidikan karakter. Evaluasi terhadap hasil dan proses belajar peserta didik harus dilakukan dengan intensif dan berkala. Peserta didik yang mendapatkan hasil kurang memuaskan (tetapi hasil kerja keras sendiri) ketika ujian, harus dicari penyebabnya. Setelah diketahui penyebabnya guru mampu mengambil tindakan sebagai solusi dari permasalahan peserta didik tersebut.

Senada dengan hal di atas Elfindri, dkk (2011:67) menguraikan beberapa cara untuk mengasah kejujuran pada peserta didik, diantaranya:

a) Guru mesti selalu menepati janji setiap yang dijanjikan kepada anak didik. Diantaranya kebiasaan untuk menetapkan masuk kelas, mengembalikan bahan atau tugas yang diperiksa oleh guru.

b) Menjaga disiplin dalam proses belajar mengajar serta proses ujian. Mereka yang mengikuti peraturan akan memperoleh reward, sementara yang melanggar ketentuan dikenakan sanksi sesuai dengan pelanggaran ketidakjujuran yang dibuat.

Tidak hanya itu saja, peran orangtua dalam mengembangkan karakter jujur sangat penting. Menurut Irwandi Rinaldi (2014) ada tiga langkah yang dapat dilakukan orangtua dalam mengembangkan karakter jujur pada anak, diantaranya:

a) Memberi tahu anak. Hal ini dapat dilakukan melalui cerita bersama anak, sehingga anak memiliki basis informasi.

b) Memberikan teladan/contoh kepada anak dan memberikan tanggung jawab. Hal ini dapat dilakukan oleh orangtua bagaimana seorang anak mampu untuk mengelola uang jajan yang diberikan kepada anak dengan baik.

c) Lakukan tindakan itu dengan berulang-ulang serta dokumentasikan.

Jika ditinjau dari pelayanan konseling, pendidikan karakter itu dapat menjadi isi/materi/topik bahasan dalam penyelenggaraan layanan atau kegiatan pendukung. Oleh karena itu guru bimbingan konseling atau konselor diharapkan mampu menjadi contoh, teladan, mediator bagi peserta didik dalam mengembangkan karakter.

Untuk mewujudkan hal ini dibutuhkan kerja sama antara orang tua, guru, guru BK dan peran masyarakat dalam mengembnagkan karakter jujur peserta didik. 


\section{Strategi Pengembangan Karakter Jujur Melalui Pembiasaan (Conditioning)}

Pembiasaan merupakan sesuatu yang sering dilakukan dalam kehidupan sehari-hari. Hal ini tercermin dalam tingkah laku seseorang untuk melakukan sesuatu. Sehingga apa yang dilakukan seseorang merupakan proses melakukan pembiasaan. Pembelajaran merupakan rangkaian proses pendidikan. Pembelajaran adalah suatu proses aktivitas membelajarkan dan belajar, di dalamnya terdapat dua subjek yang saling terlibat, yaitu guru dan peserta didik.

Para psikolog menyepakati bahwa bentuk belajar yang paling sederhana adalah pembiasaan (conditioning). Ini bukan berarti bahwa pembiasaan adalah proses yang tidak komplit, melainkan pembiasaan sebagai suatu bentuk belajar yang sudah diobservasi pada organisme yang lebih rendah dari manusia dan ditemukan bahwa ini merupakan bentuk belajar yang lebih mendasar dibandingkan proses belajar seperti konsep, berfikir, dan pemecahan masalah.

Dengan demikian dapat dipahami bahwa pembelajaran manusia yang lebih kompleks membutuhkan penggabungan dari prinsip-prinsip pada kajian tentang pembiasaan. Salah satunya dengan menggunakan pendekatan tingkah laku atau behavioral yang menekankan pada dimensi kognitif individu dan menawarkan berbagai metode yang berorientasi pada tindakan (action-oriented) untuk membantu mengambil langkah yang jelas dalam mengubah tingkah laku.

Teori belajar ini terfokus pada munculnya respons terhadap berbagai stimulus. Seseorang dikatakan belajar apabila mengalami perubahan tingkah laku kearah yang positif. Oleh karena itu pengukuran terhadap stimulus dan respons merupakan hal yang penting. Di samping itu juga ada faktor lain yang dianggap berperan yaitu penguatan (Reinforcement), apabila penguatan ditambah (positive reinforcement) maka respon akan semakin kuat, dan sebaliknya. Hal ini merupakan salah satu teknik yang dapat dilakukan oleh seorang guru dalam pengembangan karakter jujur peserta didik.

Dalam penyelenggaraan pembiasaan perlu memperhatikan beberapa prinsip. Menurut Henry C. Ellis (1978) prinsip pembiasaan adalah sebagai berikut:

1. Acquisition (Perolehan). Respon yang memperoleh penguatan akan menguat secara berangsur-angsur dan sebaliknya.

2. Extinction (Pemadaman). Pemadaman merupakan penurunan intensitas kekuatan respon yang semakin sering tidak terlihat sampai menghilang.

3. Spontaneous Recovery (Pengembalian Spontan). Pengembalian spontan menunjukkan munculnya kembali respon yang telah mengalami pemadaman. Ini menunjukkan bahwa kecenderungan perilaku masih ada walaupun respon telah dihilangkan sebelumnya.

4. Generalization (Generalisasi). Belajar pada satu situasi atau konteks bisa digeneralisasikan pada konteks atau situasi yang lain, namun yang situasinya mirip. Dengan demikian prinsip dasarnya adalah bahwa suatu respon yang dipelajari pada sutua stimulus dan ada stimulus lain yang mirip dengan itu, maka akan menghasilkan respon yang sama.

5. Discrimination (Pembedaan). Proses pembelajaran untuk memberikan respon secara berbeda-beda terhadap stimulus yang mirip dinamakan dengan pembedaan stimulus. Proses ini merupakan bentuk dasar dari semua pembelajaran. Faktor-faktor yang mempengaruhi pembedaan stimulus antara lain, kemiripan, kekonsistenan dan dimensi kerelavansian. Semakin besar tingkat kemiripan semakin sulit orang membedakannya.

6. Differentiation (Perbedaan). Perbedaan adalah proses yang mirip dikuatkan secara berbeda. Dalam hal ini satu respon dikuatkan sementara respon yang lain dilemahkan.

Berdasarkan uraian di atas prinsip pembiasaan sangat diperlukan dalam proses pembelajaran khususnya dalam pembentukan tingkah laku. Indivdu akan tetap melakukan suatu kebaikan jika mendapatkan respon yang positf dari lingkungan (adanya stimulus-respons dan reinforcement), begitu sebaliknya.

Prinsip yang mendasar adalah bahwa perilaku yang tidak sehat juga diperoleh melalui pembiasaan. Sebagaimana mengembangkan karakter jujur diperoleh melalui pembiasaan, maka berbohong/berdustapun yang merupakan perilaku menyimpang tentunya diperoleh dari pembiasaan, yakni dari belajar. 


\section{PENUTUP}

Salah satu tujuan utama pendidikan adalah membentuk kejujuran, karena kejujuran adalah modal dasar dalam kehidupan bersama dan kunci menuju keberhasilan. Melalui kejujuran kita dapat mempelajari, memahami, dan mengerti tentang keseimbangan dan keharmonisan. Hal ini dapat terwujud dengan adanya kerja sama antara keluarga, sekolah dan masyarakat melalui pembiasaan (stimulus-respons-reinforcement).

\section{DAFTAR PUSTAKA}

Alfairuuzy.( 2013). Penanaman Nilai-Nilai Kejujuran Dalam Pendidikan Menjadi Solusi Atas Krisis Moral Dalam Sistem Pemerintahan Masa Depan. (Online), (http://alfairuzy.blogspot.com). Diakses 22 November 2012)

Daharnis. (2013). Pendidikan Karakter dalam Pelayanan Konseling. Padang: Sukabina Press.

Departemen Agama RI. (2005). Mushaf Al Qur'an Terjemah. Jakarta: Al-Huda

Depdikbud. (1997). Kamus Besar Bahasa Indonesia. Jakarta: Balai Pustaka

Elfindri, dkk. (2011). Soft skills untuk pendidik. Batam: Baduose Media

Emosda. (2013). Penanaman Nilai-Nilai Kejujuran Dalam Menyiapkan Karakter Bangsa. (Online), (http://www.unja.ac.id/fkip. diakses 22 November 2013)

Henry C. Ellis. (1978). Fundamentals of Human Learning, Memory and Cognition.

Irwandi Rinaldi. (2014). Kiat Menanamkan Karakter Pada Anak. Makalah disampaikan pada Seminar Parenting. LPMP Sumbar, 22 Februari 2014

Kementerian Pendidikan Nasional, Badan Penelitian dan Pengembangan Pusat Kurikulum (2010a). Pengembangan Pendidikan Budaya dan Karakter Bangsa : Pedoman Sekolah. Jakarta: Depdiknas

Kementerian Pendidikan Nasional, Badan Penelitian dan Pengembangan Pusat Kurikulum. 2010b. Bahan Pelatihan Penguatan Metode Pembelajaran Berdasarkan Nilai-Nilai Budaya untuk Membentuk Daya Saing dan Karakter bangsa. Jakarta: Depdiknas

Kementerian Pendidikan Nasional, Badan Penelitian Dan Pengembangan Pusat Kurikulum dan Perbukuan. (2011a). Panduan Pelaksanaan Pendidikan Karakter. Jakarta: Depdiknas.

Masnur Muslich. (2011). Pendidikan Karakter. Jakarta: Bumi Aksara.

Muhibbin Syah. (2009). Psikologi Belajar. Bandung: Remaja Rosdakarya.

Parayitno dan Afriva Khaidir. (2011). Model Pendidikan Karakter Cerdas. Padang: UNP Press

Sa’id Hawwa. (2007). Kajian Lengkap Penyucian Jiwa. Jakarta: Darussalam

Undang-undang Republik Indonesia Nomor 20 tahun 2003 tentang Sistem Pendidikan Nasional.

Zainal Aqib. (2012). Pendidikan Karakter di Sekolah Membangun Karakter dan Kepribadian Anak. Bandung: Yrama Widya 